\title{
Współpraca Biura Pełnomocnika Rządu d/s Polskiego Dziedzictwa Kulturalnego za Granicą ze wschodnimi sąsiadami ${ }^{1}$
}

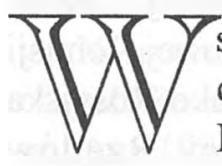

spółpraca ze wschodnimi sąsiadami prowadzona jest w oparciu o Porozumienia i umowy dwustronne wynegocjowane przez Pełnomocnika Rządu ds. Polskiego Dziedzictwa Kulturalnego za Granicą z Pełnomocnikami Rządów Białorusi, Rosji i Ukrainy. Podpisanie stosownego Porozumienia jest przewidziane rówież z Litwą. Podstawą Porozumień, Deklaracji i Protokołów o Współpracy są uprzednio podpisane traktaty. Odpowiednie zapisy zawarte w tych dokumentach pozwoliły na utworzenie komisji mieszanych, których posiedzenia odbywają się zwykle dwa razy w ciagu roku.

Komisja Konsultacyjna Polsko-Białoruska ds. Dziedzictwa Kulturalnego powstała przed podpisaniem Porozumienia między Rządami obu państw. Została utworzona na podstawie Deklaracji o współpracy kulturalnej, naukowej i edukacyjnej, podpisanej w Mińsku 18 listopada 1992 roku.

Natomiast 25 marca 1995 roku zostało podpisane Porozumienie między Rządem Rzeczypospolitej Polskiej a Rządem Republiki Białoruś o współpracy w dziedzinie ochrony środowiska kulturalnego.

Pracom Komisji Przewodniczy prof. Andrzej Ciechanowiecki. Na jej czele stoja, ze strony polskiej: Pełnomocnik Rządu ds. Polskiego Dziedzictwa Kulturalnego za Granica, ze strony białoruskiej: Pełnomocnik Rządu Republiki Białoruś Przewodniczący Państwowej Inspekcji ds. Ochrony Dziedzictwa Kulturalnego.

W ramach Komisji pracują cztery zespoły ekspertów, którym ze strony polskiej przewodniczą: ds. zabytków nieruchomych - dr Maria KałamajskaSaeed z Instytutu Sztuki PAN; ds. zabytków ruchomych - dr Tadeusz Bernatowicz, adiunkt w Instytucie Historii Sztuki Uniwersytetu Warszawskiego; ds. bibliotek - dr Zoja Jaroszewicz-Pieresławcew, adiunkt w Zakładzie Bibliotekoznawstwa Wyższej Szkoły Pedagogicznej w Olsztynie; dla archiwów - dr Andrzej Biernat, Dyrektor Generalny w Naczelnej DyZ Badań Nad Polskimi Księgozbioram Historycznymi

t. 19, Warszawa 1999. 
rekcji Archiwów Państwowych. Ponadto w pracach Komisji uczestniczy dr Andrzej Michałowski, Dyrektor Ośrodka Ochrony Zabytkowego Krajobrazu, jako organizator Akademii Nieświeskiej. Sekretarzem Komisji jest mgr Anna Różycka z Biura Pełnomocnika Rządu ds. Polskiego Dziedzictwa Kulturalnego za Granicą.

18 maja 1994 roku podpisano Porozumienie o współpracy w dziedzinie ujawniania i zwrotu dóbr kultury przemieszczonych na obszar drugiego państwa pomiędzy Pełnomocnikiem Rządu Rzeczypospolitej Poiskiej a Pełnomocnikiem Rządu Federacji Rosyjskiej w Rzeczypospolitej Polskiej ds. Dziedzictwa Kulturalno-Historycznego, członkiem Państwowej Komisji ds. Restytucji Dóbr Kultury, na podstawie którego pracuje Polsko-Rosyjska Komisja Ekspertów. Na jej czele stoją Pełnomocnicy Rządów obu państw. W jej skład ze strony polskiej wchodzą eksperci z Muzeum Narodowego w Warszawie: mgr Andrzej Bobrow, dr Anna Tyczyńska, mgr Krystyna Znojewska oraz mgr Monika Kuhnke z Biura Pełnomocnika Rządu ds. Polskiego Dziedzictwa Kulturalnego za Granicq.

Rozmowy dotyczą dzieł sztuki, których znane jest obecne miejsce przechowywania, bądź są podstawy do tego, aby sądzić, iż obiekty te znajdują się na terytorium drugiego państwa. Dodatkowo eksperci dokonują wymiany informacji dotyczących archiwaliów, które mogą być pomocne w ustalaniu kierunków wywozu dzieł sztuki podczas II wojny światowej.

Od 1994 roku strona polska złożyła piętnaście wniosków rewindykacyjnych dotyczących dzieł sztuki i przedmiotów. Są to: konsola z 1766 r. wykonana na zamówienie St. A. Poniatowskiego, należąca do wyposażenia Sali Tronowej Zamku Królewskiego w Warszawie; obrazy Pompeo Batoniego: Apollo i dwie Muzy oraz Alegoria architektury, malarstwa i rzeźby z pałacu w Wilanowie; 28 eksponatów i 31 dokumentów z obozu koncentracyjnego Auschwitz-Birkenau; kustodia z Raciborza datowana na 1495 r.; 33 wazy gołuchowskie z kolekcji XX. Czartoryskich w Gołuchowie; rysunki i grafiki pochodzące z gdańskiej kolekcji J. Kabruna (6860 prac); obraz Madonna z Dzieciątkiem Lucasa Cranacha, pochodzący z kościoła w Głogowie; obraz Król Władysław IV i hołd Malborka Bartłomieja Strobla z ok. 1640 roku, wywieziony z Muzeum w Toruniu; tryptyk ze sceną Wniebowzięcia Najświętszej Marii Panny z 1521 roku, pochodzący z kościoła w Szamotułach; szafa relikwiarzowa datowana na 1390 rok, z kościoła w Kwidzynie; puchary: cechu piekarzy i cechu gdańskich szyprów wiślanych wykonane w 1710 i w 1738 roku przez Michaela Dietricha; puchar bractwa św. Rajnolda wykonany przez Caspra Beutmülera pod koniec 
XVII wieku; zwieńczenie pucharu w formie statku żaglowego autorstwa Samuela Gräve z 1747 roku.

Do tej pory jedno $\mathrm{z}$ wymienionych dzieł sztuki powróciło do Polski. 29 października 1997 roku nastąpiło przekazanie stronie polskiej obrazu Pompeo Batoniego Apollo i dwie Muzy, który od zakończenia II wojny światowej znajdowal się w Pawłowsku. Strona rosyjska otrzymała w zamian akwarelę Widok Monrepos koło Ludwigsburga dawniej należącą do wyposażenia pałacu w Gatczynie, a od 1945 roku przechowywaną w Muzeum Narodowym we Wrocławiu.

Na podstawie Protokolu o wspólpracy między Ministerstwem Kultury i Sztuki Rzeczypospolitej Polskiej a Ministerstwem Kultury i Sztuki Ukrainy na lata 1996-1997 z 25 listopada 1995 roku, została powołana Komisja ds. ochrony dziedzictwa kulturalnego. ${ }^{2} \mathrm{Z}$ tym, że jak do tej pory, została utworzona tylko polska część Komisji. Ze strony ukraińskiej nie został przesłany jej skład personalny i mimo wielokrotnych zaproszeń wystosowanych przez stronę polską do spotkania nie doszło. 23 kwietnia ze strony polskiej zostali powołani: prof. Tadeusz Polak - przewodniczący, prof. Ryszard Brykowski, prof. Krzysztof Migon, prof. Jan Ostrowski, dr Andrzej Biernat, dr Tadeusz Rudkowski, dr Janusz Smaza, dr Łukasz Kądziela, mgr Andrzej Betlej, mgr Ryszard Bobrow, mgr Jerzy Petrus, mgr Jacek Miler - sekretarz.

15 grudnia 1996 roku, na podstawie Porozumienia między Rządem Rzeczypospolitej Polskiej a Rządem Ukrainy o współpracy w dziedzinie ochrony i zwrotu dóbr kultury utraconych i bezprawnie przemieszczonych podczas Il wojny Światowej, powstała Międzyrządowa Komisja Polsko-Ukraińska dla ochrony i zwrotu dóbr kultury utraconych i bezprawnie przemieszczonych podczas II wojny światowej. Przewodniczącymi zostali: ze strony polskiej prof. Tadeusz Polak - Podsekretarz Stanu w Ministerstwie Kultury i Sztuki, Pełnomocnik Rządu ds. Polskiego Dziedzictwa Kulturalnego za Granicą ze strony ukraińskiej: prof. Aleksander Fedoruk - Przewodniczący Narodowej Komisji ds. Powrotu do Ukrainy dóbr Kultury przy Gabinecie Ministrów Ukrainy. Ze strony polskiej w skład Komisji zostali powołani: prof. Barbara Bieńkowska - Prezes Polskiego Towarzystwa Bibliologicznego; dr Andrzej Biernat - Dyrektor Generalny w Naczelnej Dyrekcji Archiwów Państwowych; dr Adolf Juzwenko - Dyrektor Biblioteki Zakładu Narodowego im. Ossolińskich we Wrocławiu; prof. Edmund Małachowicz Przewodniczący Rady Ministra Kultury i Sztuki ds. Ochrony Zabytków; prof. Adam Manikowski - Dyrektor Biblioteki Narodowej w Warszawie; 
prof. Jan Ostrowski - Dyrektor Państwowych Zbiorów Sztuki na Wawelu; prof. Jan Pruszyński - z Katedry Państwa i Prawa Polskiej Akademii Nauk; prof. Tadeusz Zalewski - Kierownik Katedry Konserwacji Dzieł Sztuki Akademii Sztuk Pięknych w Krakowie. Sekretarzem Komisji jest Jacek Miler z Biura Pełnomocnika Rządu ds. Polskiego Dziedzictwa Kulturalnego za Granicą. Pierwsze spotkanie Komisji odbyło się we Lwowie w dniach 14-16 maja 1997 roku. Do najważniejszych ustaleń zawartych w Protokole należą między innymi: punkt 7, w którym postanowiono powołać polsko-ukraińskie zespoły ekspertów do spraw archiwaliỏw historycznych; zasobów bibliotecznych; dzieł sztuki oraz osobny zespół ekspertów ds. Ossolineum oraz punkt 8 , który mówi, iż wnioski rewindykacyjne będą składane przez Współprzewodniczących Komisji drogą dyplomatyczna.

Pełnomocnik Rządu wywiązując się z punktu 7 podpisanego Protokołu powołał zespoły ekspertów w następującym składzie:

- dla archiwaliów historycznych: dr Andrzej Biernat, dr Jan Basta, dr Sławomir Radoń, mgr Andrzej Litewka, mgr Janusz Szymański;

- ds. bibliotek: prof. Krzysztof Migoń, mgr Hanna Łaskarzewska, dr Zdzisław Pietrzyk;

- ds. dzieł sztuki: prof. Jan Ostrowski, dr Elżbieta Charazińska, mgr Ryszard Bobrow, dr Jerzy Petrus

- ds. Ossolineum: dr Adolf Juzwenko, mgr Stanisław Kozak, dr Maciej Matwijów, mgr Ryszard Nowakowski, dr Urszula Paszkiewicz, dr Wiesław Tyszkowski, dr Roman Wytyczak.

Zgodnie z punktem 8 Protokołu, do tej pory Pełnomocnik Rządu złożył siedem wniosków rewindykacyjnych. Wnioski te dotyczą: Zakładu Narodowego im. Ossolińskich; księgozbioru Witolda K. Czartoryskiego; zbiorów Bolesława Orzechowicza; zbiorów Józefa Smolińskiego, dwóch luf armatnich, będących przed II wojną depozytem Państwowych Zbiorów Sztuki na Wawelu; Madonny dhuta Cypriana Godebskiego; pamiątek historycznych i regaliów znajdujących się przed wojną w Muzeum Narodowym im. Jana III Sobieskiego we Lwowie.

Drugie spotkanie, zgodnie z punktem 9 Protokołu, które miało się odbyć w Polsce w październiku 1997 roku, zostało przełożone na wniosek strony ukraińskiej na kwiecień 1998 roku. Do tej pory nie zostały przekazane wnioski rewindykacyjne strony ukraińskiej, jak również nie jest znany skład ukraińskich zespołów ekspertów.

Zgodnie z zawartymi Porozumieniami, Biuro Pełnomocnika Rządu 
ds. Polskiego Dziedzictwa Kulturalnego (zwane dalej: Biuro) uczestniczy w pracach dokumentacyjnych i konserwatorsko-budowlanych wobec zabytków znajdujących się za wschodnią granicą Polski. Większość z nich znajduje się obecnie na terenie Litwy, Białorusi i Ukrainy. Prowadzone prace mają na celu zlokalizowanie i zinwentaryzowanie zabytków kultury polskiej i z Polską związanych. Zbieranie informacji ma charakter wielotorowy, z wykorzystaniem wszystkich możliwych źródeł. Są to między innymi: kwerendy archiwalne, biblioteczne i ikonograficzne; prace inwentaryzacyjne w terenie; materiały pozyskiwane dzięki współpracy $z$ instytucjami w kraju i za granica, a także z osobami prywatnymi. Uzyskiwane materiały to: karty inwentaryzacyjne, zdjęcia, oraz wykazy i opracowania. Specjalnie przygotowane programy komputerowe pozwalają na rejestrowanie danych na temat architektury i zabytków ruchomych. Biuro Pełnomocnika Rządu współpracuje ze stowarzyszeniami i instytucjami, które od lat są zaangażowane w prace na Wschodzie. Należą do nich między innymi: Instytut Sztuki PAN, Stowarzyszenie „Wspólnota Polska”, Ośrodek Ochrony Zabytkowego Krajobrazu, Koło Naukowe Studentów Historii Sztuki Uniwersytetu Warszawskiego, Koło Naukowe Studentów Historii Sztuki Uniwersytetu Jagiellońskiego, Akademia Sztuk Pięknych w Warszawie, Politechnika Świętokrzyska, Światowy Związek Żołnierzy Armii Krajowej, Fundacja Kultury Polskiej czy też Fundacja Ochrony Zabytków.

Należy także wspomnieć, iż realizację wielu zadań Biura zapewnia współpraca z Ministerstwem Spraw Zagranicznych, a zwłaszcza z placówkami dyplomatycznymi w Moskwie, Wilnie, Mińsku, Grodnie, Kijowie i we Lwowie.

Biuro dofinansowuje lub finansuje w całości prace inwentaryzacyjne prowadzone przez studentów. Inwentaryzację zabytków na Litwie i Białorusi prowadzi Sekcja Wschodnia Koła Naukowego Studentów Historii Sztuki Uniwersytetu Warszawskiego, których opiekunem naukowym jest dr Maria Kałamajska-Saeed z Instytutu Historii Sztuki PAN. Dotychczas zinwentaryzowano zabytki na terenie Białorusi: w obwodzie grodzieńskim i część obwodu witebskiego zaś na Litwie: część rejonów wileńskiego i kowieńskiego. Oprócz prac w terenie wykonywane są kwerendy archiwalne, w tym również za granicą. Niebawem prace te zaowocują I tomem publikacji dotyczącej kościołów i klasztorów w Grodnie.

Na terenie Ukrainy inwentaryzacją zabytków sztuki sakralnej zajmuje się Koło Naukowe Studentów Historii Sztuki Uniwersytetu Jagiellońskiego. W roku 1997 prace inwentaryzacyjne przeprowadzono w obwodzie tar- 
nopolskim. Wyniki z prowadzonych prac są publikowane w serii: Materiały do dziejów sztuki sakralnej na Ziemiach Wschodnich dawnej Rzeczypospolitej, część I Kościoły i klasztory rzymskokatolickie dawnego województwa ruskiego. ${ }^{3}$ Do tej pory wydano 4 tomy, następne są w przygotowaniu. Opiekunem naukowym całego przedsięwzięcia jest prof. Jan Ostrowski.

Równolegle jest prowadzona inwentaryzacja cmentarzy. W latach 19941995 studenci Politechniki Świętokrzyskiej zinwentaryzowali cmentarz w Żytomierzu, a w latach 1996-1997 Cmentarz Bajkowski w Kijowie. Prace studentów koordynuje Ośrodek Ochrony Zabytkowego Krajobrazu. Ponadto Ośrodek ds. Polskiego Dziedzictwa Kulturowego poza Granicami Kraju, działający w ramach Stowarzyszenia „Wspólnota Polska”, zinwentaryzował cmentarze w Kołomyji, Drohobyczu, Połonnem i Zbarażu (I etap). Katalogi tych cmentarzy zostaną opublikowane w wydawanej przez Biuro Pełnomocnika Rządu serii „Wspólne Dziedzictwo”.

Biuro finansuje w całości lub dofinansowuje również prace konserwatorsko-budowlane prowadzone w niektórych obiektach zabytkowych na Wschodzie. Należą do nich między innymi: kościoły w Moskwie, Petersburgu, Irkucku, Nieświeżu, Nowogródku, Wołożynie, Lubomlu, Rudkach, Ołyce, Berdyczowie i katedrze we Lwowie. Dofinansowano także prace remontowe na zamku w Zloczowie i remont dachu dworu w Poszeszuwiu. Przeprowadzono także prace zabezpieczające ruiny zamku w Nowogródku. Dzięki finansowemu wsparciu Biura Pełnomocnika wykonano konserwację dwunastu obrazów z kościoła pobrygidkowskiego w Grodnie. W 1997 roku rozpoczęto: prace konserwatorskie przy dwóch obrazach w katedrze w Łuku, obrazu św. Trójcy kościele w Szyłanach, rekonstrukcję i konserwację epitafium gen. Józefa Dwernickiego. Wykonano także konserwację pomnika Adama Mickiewicza w Drohobyczu oraz płytę pamiątkową poświęconą Mikołajowi Rejowi w Żurawnie. Prowadzone są również prace konserwatorskie w kościele pw. św. Wawrzyńca w Żółkwi. Ze środków Biura, Fundacja Ochrony Zabytków przeprowadziła konserwację ołtarza św. Trójcy. Natomiast studenci Akademii Sztuk Pięknych w Warszawie i Krakowa, pod kierownictwem naukowym dr Janusza Smazy, wykonują prace konserwatorskie nagrobków Żółkiewskich, Daniłowiczów i Sobieskich.

Biuro Pełnomocnika Rządu prowadzi prace badawcze na temat strat książki w granicach Polski z 1939 roku. Informacje o tych stratach będą dopetnieniem Raportu o stratach bibliotek z granicach Polski z roku 1945. Na ukończeniu jest inwentaryzacja Biblioteki Stanisława Augusta Poniatowskiego, znajdującej się w Bibliotece Narodowej Ukrainy w Kijowie. ${ }^{4}$ 
Z innych inicjatyw finansowanych przez Biuro, warto tu wspomnieć o działalności Akademii Nieświeskiej, mającej charakter studiów podyplomowych. Stroną organizacyjną i merytoryczną przedsięwzięcia zajmuje się Ośrodek Ochrony Zabytkowego Krajobrazu. Biorą w niej udział obywatele Litwy, Białorusi i Ukrainy. Do tej pory zajęcia dotyczyły problematyki związanej z ochroną parków i cmentarzy.

Ponadto Biuro dofinasowuje publikacje, wystawy, sesje i konferencje naukowe poświęcane zabytkom na Wschodzie.

Wszystkie wymienione powyżej prace prowadzone są przy współpracy z wieloma instytucjami i za zgodą odpowiednich władz w Rosji, na Białorusi, Litwie i Ukrainie. Na przykład akcja inwentaryzacyjna zabytków na Białorusi jest prowadzona dzięki zezwoleniu wydawanemu przez Pełnomocnika Rządu Republiki Białoruś, Przewodniczącego Państwowej Inspekcji ds. Ochrony Dziedzictwa Kulturalnego. Wyjazdy na Ukrainę mają miejsce po uprzednim poinformowaniu przez Pełnomocnika Rządu - Ministra Kultury i Sztuki Ukrainy. Informacja zawiera: cel wyjazdu, teren działania i nazwisko opiekuna grupy.

Jako przykład współpracy przy pracach konserwatorskich można wymienić I etap konserwacji obrazu św. Trójcy w kościele w Szyłanach. Prace te były nadzorowane przez Stowarzyszenie „Wspólnota Polska” i wykonywane wspólnie z konserwatorami litewskim, w uzgodnieniu z Departamentem Konserwacji litewskiego Ministerstwa Kultury.

$\mathrm{Na}$ Białorusi od trzech lat działa Akademia Nieświeska, która powstała przy współpracy z Ministerstwem Kultury i Druku Republiki Białoruś.

Natomiast specjaliści białoruscy z Instytutu Konserwatorskiego w Mińsku, pod nadzorem Ośrodka Ochrony i Konserwacji Zabytków, wykonywali prace zabezpieczające m.in. ruiny zamku w Nowogródku.

Wśród instytucji współpracujących z Biurem, na Ukrainie szczególne miejsce zajmuje Instytut Konserwatorski we Lwowie „Ukrzachidprojektrestavracja”. Dzięki niemu prowadzana przez Biuro ewidencja zabytków wzbogaciła się o setki kart inwentaryzacyjnych obiektów architektury sakralnej, dworów i założeń pałacowo-ogrodowych oraz wiele kart inwentaryzacyjnych nagrobków Cmentarza Łyczakowskiego.

W zakresie ochrony dziedzictwa kulturalnego pozostało jeszcze wiele do zrobienia. W tym celu konieczna jest współpraca wszystkich stowarzyszeń i instytucji do tego powołanych oraz władz państwowych i samorządowych zarówno w Polsce, jak i na Białorusi oraz na Ukrainie. Dla polepszenia warunków współpracy z Litwą konieczne jest możliwie jak najszybsze pod- 
pisanie stosownego Porozumienia między Pełmomocnikami Rządów obu Państw.

Ilość wykonanych prac przede wszystkim będzie uzależniona od sytuacji gospodarczej w tych państwach i nakładów finansowych przeznaczanych na ochronę zabytków. Ze względu na zły stan zachowania istnieje pilna potrzeba wykonania prac remontowych i konserwatorskich wielu obiektów zabytkowych. Na Białorusi należą do nich między innymi wyposażenie kościoła w Krzemienicy czy też ołtarz w kościele w Wołpie. Na Ukrainie można wymienić: kościół w Zbarażu, kaplicę Sieniawskich w Brzeżanach i dworek Słowackich w Krzemieńcu. Należy również rozpocząć prace konserwatorskie na Cmentarzu Lyczakowskim we Lwowie.

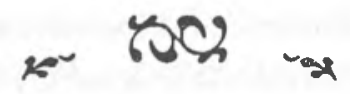

Przypisy:

${ }^{1}$ Artykuł stanowi skróconą wersję referatu przedstawionego podczas IV Forum PTB w dn. 2 grudnia 1997 r. w Warszawie. Część materiału dotyczącego prac Biura na Wschodzie była publikowana przez autora w dwumiesięczniku: Cenne, bezcenne, utracone, nr 3/97, s. 27.

${ }^{2}$ Niektóre problemy dotyczące ochrony dóbr kultury są omawiane podczas spotkań Komitetu Konsultacyjnego Prezydentów Polski i Ukrainy. Komitet powstal w 1993 roku.

${ }^{3}$ Do tej pory zostały opublikowane: T. 1, Kraków 1993; T. 2: Petrus J.: Kościoly i klasztory Żólkwi, Kraków 1994; T. 3, Kraków 1995; T.4, Kraków 1996.

${ }^{4}$ W spólpraca dotycząca bibliotek została omówiona w referatach: B. Bieńkowskiej, H. Łaskarzewskiej i U. Paszkiewicz. 